\title{
Fluctuating Asymmetry in Melipona scutellaris (L.) 1811 (Hymenoptera: Apidae) Associated to Stress due to Transportation of Colonies
}

\author{
BR ANDRAdE ${ }^{1}$, EB SANTOS ${ }^{2}$, LA Nunes ${ }^{3}$, AS NASCIMENTO ${ }^{1}$, CAL DE CARVALho ${ }^{1}$ \\ 1 - Universidade Federal do Recôncavo da Bahia - UFRB, Cruz das Almas-BA, Brasil \\ 2 - Universidade Estadual de Santa Cruz - UESC, Ilhéus-BA, Brasil \\ 3 - Universidade Estadual do Sudoeste da Bahia - UESB, Jequié-BA, Brasil
}

\section{Article History}

\section{Edited by}

Cândida Aguiar, UEFS, Brazil

Received 27 January 2020

Initial acceptance 03 July 2020

Final acceptance 22 July 2020

Publication date 30 September 2020

\section{Keywords}

Stingless bee, uruçu, shape, forewing, migrating meliponiculture.

\section{Corresponding author}

Brunelle Ramos Andrade

Centro de Ciências Agrárias, Ambientais

e Biológicas, Universidade Federal do

Recôncavo da Bahia

Rua Rui Barbosa no 710, Centro,

44380-000, Cruz das Almas-BA, Brasil.

E-Mail: insecta@ufrb.edu.br

\begin{abstract}
Transportation to long distances and handling of colonies can affect development and survival conditions of bees. Our study investigated the stress intensity of individuals of Melipona scutellaris Latreille, 1811, due to transportation of colonies to long distances, within the natural range of the species. We used 746 bee workers. The right and left forewings were removed and measured using 15 landmarks in vein insertions. Individuals were divided into four groups: (1) workers collected the origin site, (2) workers emerged at the place of destination in pupal stage during transportation, (3) workers emerged at the destination site in the $3^{\text {rd }}$ instar of larval stage during transportation, and (4) workers collected after three months of colony establishment at the destination site. The Procrustes ANOVA showed significant results as well as the presence of Fluctuating Asymmetry (FA) in all treatments for the shape of wings $(P<0.01)$. However, in the comparison of groups using the OneWay ANOVA, only workers that emerged at the destination site in the $3^{\text {rd }}$ instar of larval stage during transportation (Group 3 ) significantly differentiated $(P<0.05)$ from the others, with a higher FA index. The larval stage underwent more stress due to colony transportation. Beekeepers should take good care of colonies during transportation in order to minimize damages to workers to prevent quality loss of services and products offered by bees.
\end{abstract}

\section{Introduction}

Bees are considered the most important and effective pollinators for the reproduction of most angiosperms (Roubik, 1989; Rech et al., 2014). Flowers benefit from pollination while providing nutritional essential resources to bees for the development and survival of individuals in the colony. Bees have holometabolic development distributed into four stages: egg (embryo), larva, pupa, and adult (Cranston \& Gullan, 2017). The first morphological and physiological transformations occur in the pupal stage, when externalization of anatomically distinct morphological structures appear and the larva passes to the adult stage (Truman \& Riddiford, 2019). During this ontogenic process, developmental noises occur, which can affect asymmetry, including the wings, and can compromise the ability of individuals to collect food or escape from predators (Møller, 1997).

Managed bees usually travel long distances from the hives in search of blooms, which is an alternative for colony survival during nectar scarcity. Moreover, it benefits pollination of agricultural crops for commercial purposes and allows an exchange of colonies to ensure genetic variability of populations, as well as the implantation of meliponaries or apiaries (vanEngelsdorp et al., 2012; Tarpy et al., 2013; Zhu et al., 2014). However, these management practices could stress bees, impairing their development, compromising their nutritional condition, and colony production (Ahn et al., 2012; Villas-Bôas, 2012; Simone-Finstrom et al., 2016a; 2016b). 
The stress caused by the transportation process of colonies affects the bee health and causes oxidative stress (Simone-Finstrom et al., 2016a; Glenny etal., 2017), influencing the ontogenetic development of individuals, as observed through the technique known as Fluctuating Asymmetry (FA) (Lima et al., 2016; Banaszak-Cibicka et al., 2018). Developmental noise is considered one of the causes that affect the individual bilaterality (Clarke, 1998; Tomkins \& Kotiaho, 2001). The FA allows identifying subtle differences in bilaterality in individuals and consequently their effects of genotypic or environmental instability. Factors associated with stress result in organisms with higher asymmetry values and consequently greater difficulty to regulate their development (adaptive fitness) (Lijteroff et al., 2008; Klingenberg, 2015).

The FA technique has been used to identify stress in bees during the ontogenic process and has been applied as a bioindicator associated to stress in the presence of pesticides during development in Apis mellifera Linnaeus, 1758 (Nunes et al., 2015) and in Melipona quadrifasciata anthidioides Lepeletier, 1836 (Prado-Silva et al., 2018). In addition, the FA is also used to assess differences in stress related to handling in rational boxes and hives in M. subnitida Ducke 1910 (Lima et al., 2016). Thus, FA is a useful and effective technique to infer ontogenetic changes in bees associated to genetic or environmental factors that lead to noise during development (Del Sarto et al., 2014).

Managed bees undergo stress during the handling and the transportation process associated to factors, such as food and temperature; however, the existence of morphological changes has not yet been observed during this transportation process and other associated factors. Thus, this study used the FA technique to evaluate the effect of stress caused by the transportation of colonies over long distances, within the area of natural distribution of the species, based on the variation of size and shape of the forewings of individuals of Melipona scutellaris.

\section{Material and Methods}

The bees used in the study were subjected to a displacement of $250 \mathrm{~km}$ for approximately $10 \mathrm{~h}$, in the daytime, at the end of October. The place of origin was the

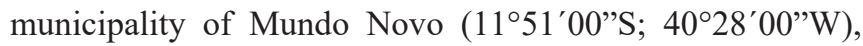
where the climate is classified as Aw (according to Köppen and Geiger), with average annual temperature $22.1{ }^{\circ} \mathrm{C}$ and average annual rainfall $875 \mathrm{~mm}$. The destination site was the municipality of Cruz das Almas (12 $39^{\circ} 11^{\prime \prime} \mathrm{S}$; $39^{\circ} 7^{\prime} 19^{\prime \prime} \mathrm{W}$ ), which has Af climate (according to Köppen and Geiger) with average annual temperature $23.0^{\circ} \mathrm{C}$ and average annual rainfall $1136 \mathrm{~mm}$. During the route, the trip was interrupted for $60 \mathrm{~min}$, from $12 \mathrm{~h} 00$ to $01 \mathrm{~h} 00$, in the municipality of Itaberaba in the state of Bahia (Fig 1). For the study, 400 adult workers of M. scutellaris were used, with 100 individuals per group. Each group was represented by 10 colonies and 10 specimens were collected in each colony. The bees were divided into four groups: (G1) workers collected at the place of origin, (G2) workers emerged at the destination site in pupal stage during transportation, (G3) workers emerged at the destination site in $3^{\text {rd }}$ instar of larval stage during transportation, and (G4) workers collected after three months of colony establishment at the destination site.

To determine the age of immature insects and establish the exact time of collection of adults, cells containing pupae and larvae were identified by the wax color, also through a small opening in three brood cells chosen at random on the brood disc (set of brood cells) investigated. Morphology of immature individuals was observed and the age of these individuals was determined. The disks (set of nest cells) of interest were marked with non-toxic water-based white paint. In these stages, the individuals were kept in the colony and were monitored in order to follow the emergence moment of bee workers.

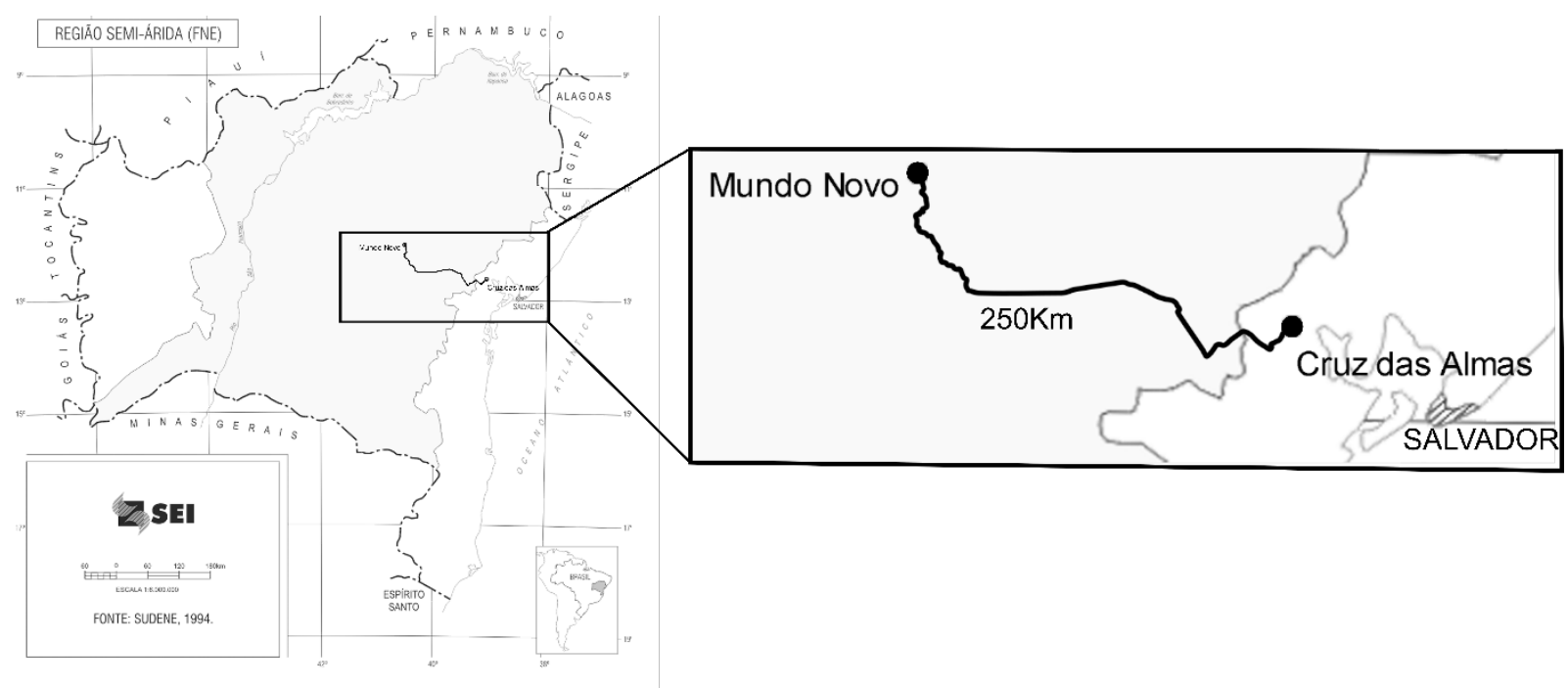

Fig 1. Route and distance of transportation of Melipona scutellaris colonies. 
The right and left forewings of the bees were removed with tweezers, placed between slides, and sealed for microscopy. Photographic records were made with a Leica $^{\circledR}$ digital camera model DFC295 coupled to a Leica ${ }^{\circledR}$ stereomicroscope model S8 APO. Only the forewings were used because, as reported in previous works (Nunes et al., 2015; Lima et al., 2016; Prado-Silva et al., 2018), there is no need to use both wings, as they have evolved to operate together. In addition, all wings were photographed by the same equipment, at the same distance, without zoom, and with the structures centralized to avoid the distortion effects of the lenses, as suggested by Klingenberg (2015). Next, the images of left wings were mirrored to be similar to the right wings to minimize measurement errors.

With the image database obtained, a tps file was generated from the images using the tpsUtil software version 1.74 (Rohlf, 2017a). We scanned 15 landmarks (Fig 2) in the vein insertions of each wing using the software tpsDig version 2.30 (Rohlf, 2017b). The wings were measured twice and by a single researcher to reduce errors associated with the measurer, as suggested by Palmer (1994).

The Cartesian coordinates obtained were used as variables for the statistical analysis. After performing the Procrustes superimposition, the Procrustes ANOVA test was applied to verify the FA level for the shape and size of the wings. The Procrustes method provides an adjustment based on values related to least squares by comparing homologous points, while the Procrustes ANOVA allows quantifying the variation in shape at different levels. It has been used mainly in asymmetry studies and in the evaluation of the amount of measurement error associated to biological variation (Palmer \& Strobeck, 2003; Klingenberg, 2015).

The FA method was applied to $M$. scutellaris individuals by varying the morphometric differences between the leftright sides between individuals. In the asymmetry analysis for the shape and size, the $\mathrm{F}$ value for the effects of sides and individuals, the side $\times$ individual interaction was used as the denominator. To check for significant differences in relation to FA, the side $\times$ individual interaction was used and the measurement of error as the denominator (Palmer, 1994; Klingenberg \& Mcintyre, 1998). The analyses were performed using the MorphoJ software version 1.06 (Klingenberg, 2011).

In addition, based on the Procrustes coordinates (shape FA scores), the One-Way ANOVA was performed in the program $\mathrm{R}$ version 3.4.1. The Tukey test was conducted to compare the means and verify differences in FA. Subsequently, a Principal Component Analysis (PCA) was performed to analyze variation in the shape of the wings between the groups.

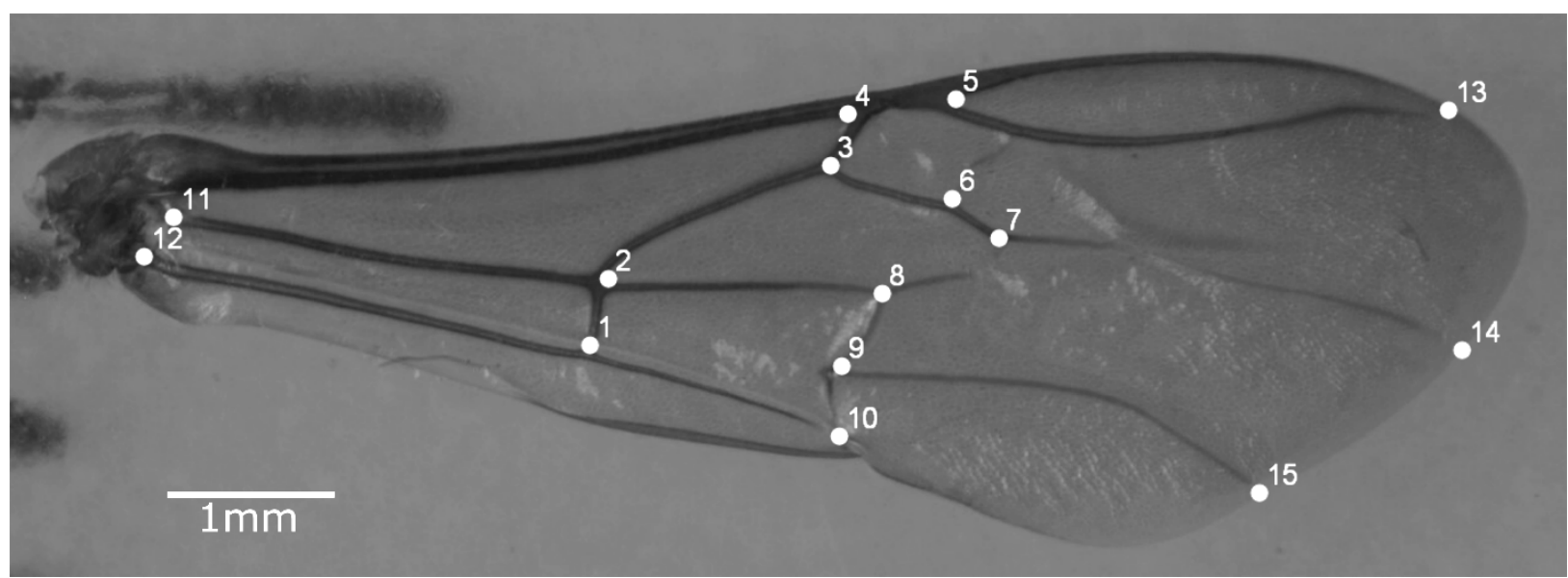

Fig 2. Right forewing of Melipona scutellaris with 15 landmarks in the vein insertion and used for the Fluctuating Asymmetry analysis.

\section{Results}

No significant results were found for FA $(\mathrm{P}>0.05)$ for the analysis of wing size from the centroid size. However, all groups evaluated separately presented significant values for FA $(\mathrm{P}<0.01)$ for the wing shape, as well as pronounced values for directional asymmetry $(\mathrm{P}>0.01)$ (Table 1$)$.

The One-Way ANOVA revealed significant differences between groups. Specifically, bee workers in the $3^{\text {rd }}$ instar of larval stage during transportation (G3) were statistically different from the others $(\mathrm{P}<0.05)$, presenting a higher FA index. In addition, the analysis of wing shape in the G4 stage showed no significant differences $(\mathrm{P}>0.05)$ after an adaptation period of three months at the destination site, when compared to individuals of the G1 stage (bees collected at the origin site) (Fig 3).

The PCA analysis showed that individuals of G3 transported in the larval stage separated on the first axis of the main component (29\%), especially from the G4 stage (Fig 4).

\section{Discussion}

All generations studied, represented by the groups G1, G2, G3, and G4, presented significant FA. Fluctuating asymmetry is largely attributed to studies that assess the impact of developmental instability (Palmer, 1994; Klingenberg, 2015). 
Table 1. The Procrustes ANOVA of wing size and shape for worker bees of the groups (G1, G2, G3 and G4) and interaction between the effects between the body side and the individual.

\begin{tabular}{|c|c|c|c|c|c|c|c|}
\hline & & Effect & SS & MS & df & $\mathbf{F}$ & $\begin{array}{c}\mathbf{P} \\
\text { (param.) }\end{array}$ \\
\hline \multirow{8}{*}{ G1 } & \multirow{4}{*}{ Centroid Size } & Individual & 4462792.65 & 45078.713637 & 99 & 0.95 & 0.6080 \\
\hline & & Side & 31760.6803 & 31760.680285 & 1 & 0.67 & 0.4162 \\
\hline & & Ind*Side & 4716286.20 & 47639.254564 & 99 & 1.00 & 0.4844 \\
\hline & & Error & 9495687.91 & 47478.439538 & 200 & - & - \\
\hline & \multirow{4}{*}{ Shape } & Individual & 0.04945959 & 0.0000192151 & 2574 & 3.79 & $<.0001$ \\
\hline & & Side & 0.00126422 & 0.0000486239 & 26 & 9.58 & $<.0001$ \\
\hline & & Ind*Side & 0.01306128 & 0.0000050743 & 2574 & 2.70 & $<.0001$ \\
\hline & & Error & 0.00976196 & 0.0000018773 & 5200 & - & - \\
\hline \multirow{8}{*}{ G2 } & \multirow{4}{*}{ Centroid Size } & Individual & 1572060.71 & 21244.063666 & 74 & 1.00 & 0.5000 \\
\hline & & Side & 43060.1051 & 43060.105050 & 1 & 2.03 & 0.1587 \\
\hline & & Ind*Side & 1572085.12 & 21244.393563 & 74 & 0.99 & 0.5176 \\
\hline & & Error & 3229930.70 & 21532.871332 & 150 & - & - \\
\hline & \multirow{4}{*}{ Shape } & Individual & 0.04117770 & 0.0000214021 & 1924 & 3.37 & $<.0001$ \\
\hline & & Side & 0.00099878 & 0.0000384144 & 26 & 6.04 & $<.0001$ \\
\hline & & Ind*Side & 0.01222677 & 0.0000063549 & 1924 & 3.37 & $<.0001$ \\
\hline & & Error & 0.00735717 & 0.0000018865 & 3900 & - & - \\
\hline \multirow{8}{*}{ G3 } & \multirow{4}{*}{ Centroid Size } & Individual & 7278243.30 & 75033.436063 & 97 & 1.00 & 0.5029 \\
\hline & & Side & 1061372.25 & 1061372.2546 & 1 & 14.1 & 0.0003 \\
\hline & & Ind*Side & 7288936.48 & 75143.675070 & 97 & 0.80 & 0.8840 \\
\hline & & Error & 16203668.0 & 93662.820942 & 173 & - & - \\
\hline & \multirow{4}{*}{ Shape } & Individual & 0.06466537 & 0.0000256405 & 2522 & 2.84 & $<.0001$ \\
\hline & & Side & 0.00105218 & 0.0000404684 & 26 & 4.48 & $<.0001$ \\
\hline & & Ind*Side & 0.02279286 & 0.0000090376 & 2522 & 4.01 & $<.0001$ \\
\hline & & Error & 0.01014514 & 0.0000022555 & 4498 & - & - \\
\hline \multirow{8}{*}{ G4 } & \multirow{4}{*}{ Centroid Size } & Individual & 2134202.14 & 21557.597355 & 99 & 0.97 & 0.5532 \\
\hline & & Side & 7393.77591 & 7393.775913 & 1 & 0.33 & 0.5647 \\
\hline & & Ind*Side & 2192545.95 & 22146.928784 & 99 & 1.01 & 0.4772 \\
\hline & & Error & 4400425.44 & 22002.127161 & 200 & - & - \\
\hline & \multirow{4}{*}{ Shape } & Individual & 0.09048487 & 0.0000351534 & 2574 & 5.24 & $<.0001$ \\
\hline & & Side & 0.00135201 & 0.0000520004 & 26 & 7.74 & $<.0001$ \\
\hline & & Ind*Side & 0.01728261 & 0.0000067143 & 2574 & 2.60 & $<.0001$ \\
\hline & & Error & 0.01342102 & 0.0000025810 & 5200 & - & - \\
\hline
\end{tabular}

(G1) workers collected at the place of origin, (G2) workers emerged at the place of destination, in pupal stage during transportation, (G3) workers emerged at the destination site, in 3rd instar of larval stage during the transportation, and (G4) workers collected after three months of colony establishment at the destination site.

Change in the animal body symmetry caused by developmental instability can be attributed to the lack of ability of an organism to withstand disturbances during its development, hindering the production of a genetically predetermined phenomenon (Clarke, 1995). Environmental factors are causes of developmental instability, such as abrupt climatic conditions, nutritional changes, pesticides, parasitism, and genetics (Parsons, 1990; Møller \& Swaddle, 1997).

The results for all groups that presented significant FA show that different factors contributed to the noise in the development of these insects. A comparative study between bees of the species Melipona subnitida Ducke,
1910 colonized in two types of nests showed that individuals showed significant asymmetry in both rearing systems. However, the comparison of nesting systems showed no significant difference between each other. In this study, Lima et al. (2016) compared pre-established colonies without the influence of a stressor factor. Another recent study showed that $M$. quadrifasciata anthidioides presented FA in the first pair of wings in both forage and newly emerged individuals (Prado-Silva et al., 2018).

Although FA occurs naturally in social bees of the genus Melipona (Lima et al., 2016; Prado-Silva et al., 2018), changes in these morphometric patterns have been reported 


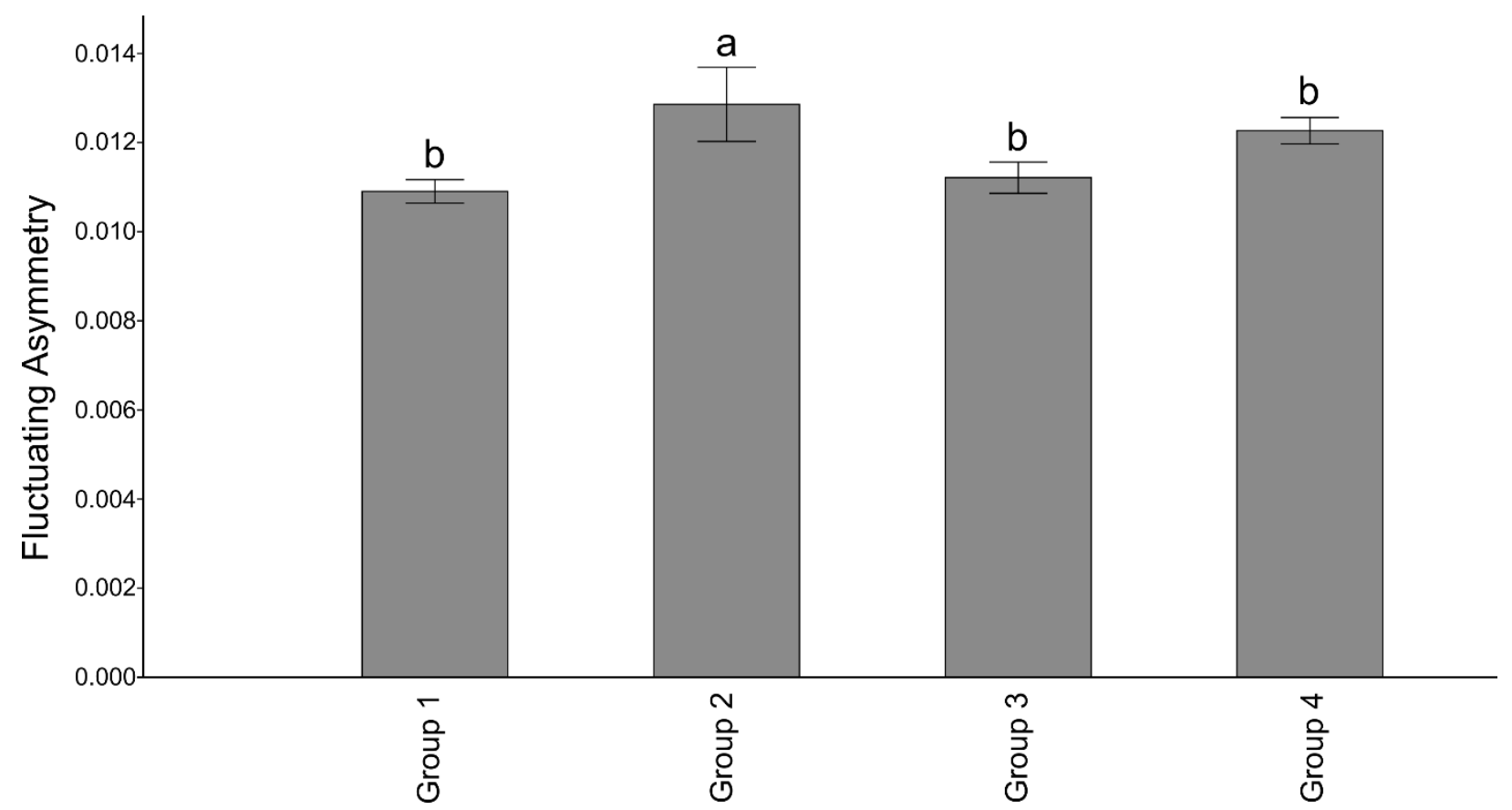

Fig 3. The Boxplot from One-Way ANOVA and the Tukey test indicating the variation of Fluctuating Asymmetry among treatments. In the Tukey test, equal letters do not differ statistically. (G1) workers collected at the place of origin, (G2) workers emerged at the place of destination, in pupal stage during transportation, (G3) workers emerged at the destination site, in 3rd instar of larval stage during the transportation, and (G4) workers collected after three months of colony establishment at the destination site.

for insects subjected to some type of stress (Prado-Silva et al., 2018). The One-Way ANOVA and PCA tests conducted in our study revealed that, in addition to FA within each group, G3 stands out for presenting higher asymmetry values, indicating greater developmental instability in this group, which was in the larval stage at the time of transport.
Among the stress factors at the time of transport, temperature was possibly the key factor to trigger an increase in asymmetry of individuals in the G3 group, caused by stress. Temperature can interfere with fecundity, population fluctuation, geographic distribution, and mainly with growth and development of insects (Paul \& Keshan, 2016; Lu et al., 2016;

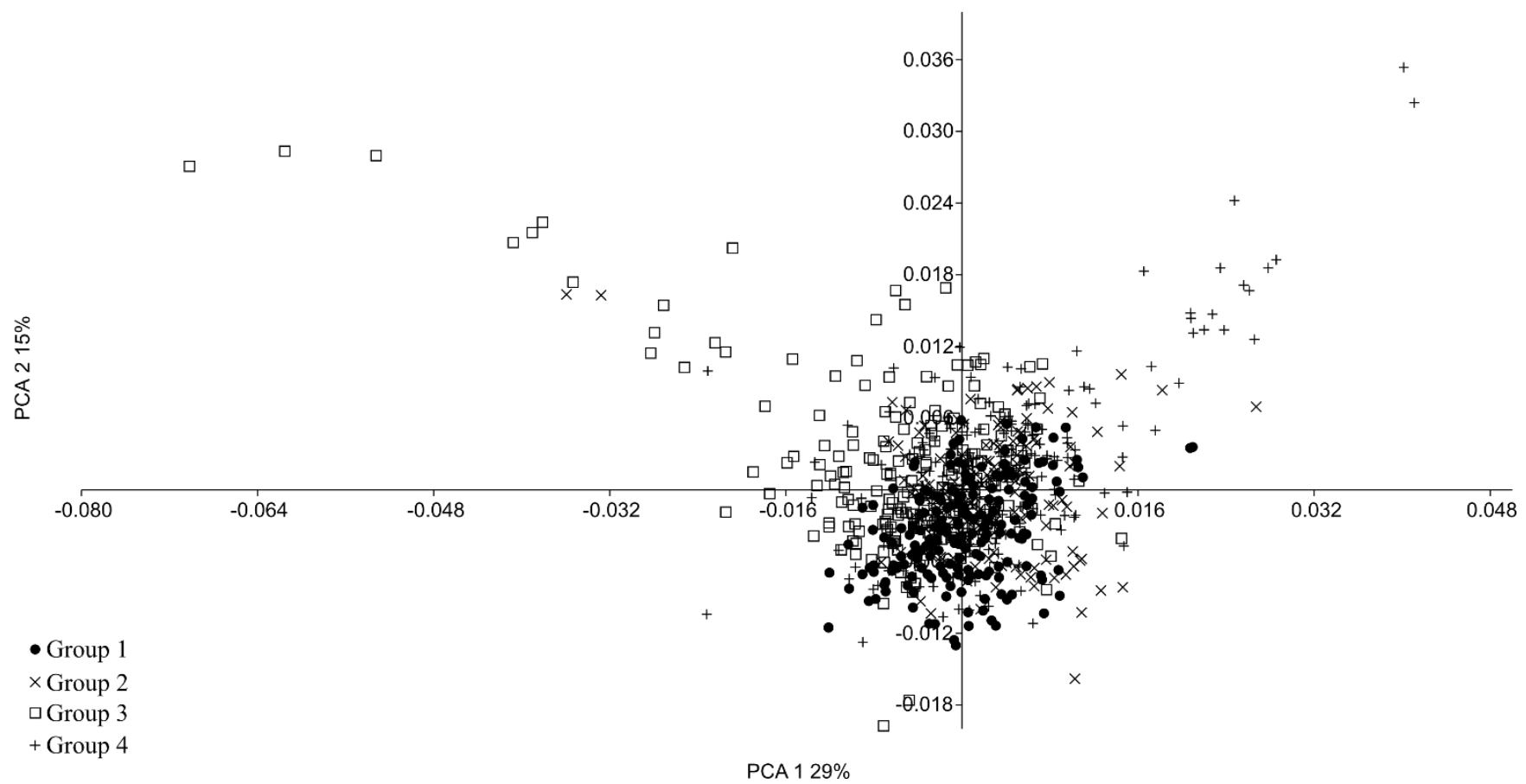

Fig 4. Principal Component Analysis for the Groups (G1, G2, G3 and G4) of Melipona scutellaris submitted to colony transport between two municipalities in the state of Bahia. (G1) workers collected at the place of origin, (G2) workers emerged at the place of destination, in pupal stage during transportation, (G3) workers emerged at the destination site, in 3rd instar of larval stage during the transportation, and (G4) workers collected after three months of colony establishment at the destination site. 
Li et al., 2017). Another important factor is that an increase in temperature can be more harmful for tropical insects, as they live close to their maximum thermal limit, compared to insects in the temperate zone (Evgen'ev et al., 2014; Paul \& Keshan, 2016). A laboratory study showed that Drosophila melanogaster Meigen, 1830 (Diptera: Drosophilidae) that developed at a temperature of $30^{\circ} \mathrm{C}$ showed an increase in FA of the sternopleural bristles, compared to individuals that developed at $25{ }^{\circ} \mathrm{C}$ (Parsons, 1990). Laboratory research on FA shows that insects undergo some type of stress in their development. Welded termites of the species Coptotermes formosanus Shiraki, 1909 and C. gestroi Wasmann, 1896 (Isoptera: Rhinotermitidae) from newly formed colonies showed significant asymmetry when compared to soldiers from colonies already established. A colony already established can ensure its homeostasis more easily; therefore, insects that grow in an established colony can overcome the developmental phase with much less stress (Chouvenc et al., 2014).

Due to the consequences that stress causes to insects, it is crucial to understand and quantify the stress level that bees suffer, especially during a transport process, to assess the impacts of abiotic and biotic factors (Simone-Finstrom et al., 2016a; Belsky \& Joshi, 2019). Transportation and handling of colonies in the implementation of apiaries and meliponaries, pollinating cultures, or changing environments in search of resources increase the stress level, especially in individuals transported in the larval stage.

When bees do not show an efficient response against the stress suffered during the physiological and behavioral processes, their activities inside the hive are compromised, as greater effort is applied in the control of homeostasis (Domingos \& Gonçalves, 2014). In addition, the greater the stress factors in the younger stages, the greater the effects on the asymmetry analysis of adult individuals. As noted by Nunes et al. (2015), individuals of Apis mellifera that develop in areas under intense use of pesticides show greater deviations in symmetry compared to populations collected under other types of stress.

Although we did not measure the temperature values inside each colony and inside the vehicle, it is worth mentioning that the transportation was carried out throughout the day and during the hottest hours. In addition, the movement was interrupted for $60 \mathrm{~min}$ in the municipality of Itaberaba. According to Climate-Data.Org, the maximum average temperature in Itaberaba, Bahia, exceeds $30{ }^{\circ} \mathrm{C}$, a value above those recorded for the municipality of origin of the evaluated colonies, Mundo Novo, Bahia, in times with lower temperatures (approximately $17{ }^{\circ} \mathrm{C}$ ). The loss of $30 \%$ of immature individuals in colonies transported compared to those who remain in fixed environments (Pires et al., 2016) could be explained by the smaller capacity of these individuals to cushion the impacts caused by transport.

Several factors generate stress during bees ontogeny, such as feeding type (Modro et al., 2012), homeothermal control (Domingos \& Gonçalves, 2014), management practices (Lima et al., 2016), and the use of pesticides (Nunes et al., 2015; Prado-Silva et al., 2018). Modro et al. (2012) showed that in summer, when temperatures are higher, individuals showed high FA levels when compared to other periods of the year. This shows deviations in the symmetry of individuals with bilateral symmetry, and FA may reflect the development of instability caused by stress due to high temperatures.

It is known that each stingless larvae receive their liquid food integrally in their brood cell even before oviposition by the queen and the larvae have direct contact with this food upon hatching. The more initial the stage of insect formation, the greater the damage they can suffer from stress. Our results of FA highlight the importance of taking great care when transporting colonies, regardless of the reason for transport, namely prioritizing days with lower temperatures, checking the resistance of colonies, and avoiding sudden temperature changes. The newly emerged bee workers analyzed ( $M$. scutellaris) were not tested for their flight capacity; however, the stress level and variation in the symmetry pattern may also affect their flight performance, success of searches, and consequently performance of bee workers (Hepburn et al., 1999).

There are no studies that investigate developmental instability between different stages in insects. Therefore, similar studies are needed to clarify issues related to the damping capacity that each stage has to overcome a stress. Moreover, these studies could bring conclusive data regarding the damage that transport, acclimatization, food, and others can cause to social bee colonies.

\section{Acknowledgements}

The authors thank the "Coordenação de Aperfeiçoamento de Pessoal de Nível Superior" (CAPES), Brazilian government (Finance Code 001) and "Conselho Nacional de Desenvolvimento Científico e Tecnológico" (CNPq) (No. 305885/2017-0).

\section{Authors' contribution}

B R Andrade: collected data and drafted the article.

E B Santos: collected data and drafted the article.

L A Nunes: designed the study, interpreted the results, and drafted the article.

A S Nascimento: designed the study, interpreted the results, and revised the article.

C A L de Carvalho: designed the study, interpreted the results, and revised the article.

\section{References}

Ahn, K., Xie, X., Riddle, J., Pettis, J. \& Huang, Z.Y. (2012). Effects of long distance transportation on honey bee physiology. Psyche, 2012: 1-9. doi: 10.1155/2012/193029 
Banaszak-Cibicka, W., Fliszkiewicz, M., Langowska, A. \& Żmihorski, M. (2018). Body size and wing asymmetry in bees along an urbanization gradient. Apidologie, 49: 297-306. doi:10.1007/s13592-017-0554-y

Belsky, J. \& Joshi, N.K. (2019). Impact of Biotic and Abiotic Stressors on Managed and Feral Bees. Insects, 10: 1-42. doi:10.3390/insects10080233

Chouvenc, T., Basille, M., Li, H.F. \& Su, N.Y. (2014). Developmental instability in incipient colonies of social insects. PLoS One, 9: 1-16. doi.org/10.1371/journal.pone. 0113949

Clarke, G. M. (1995). Relationships between developmental stability and fitness: Application for conservation biology. Conservation Biology, 9: 18-24. doi: 10.1046/j.15231739.1995.09010018.x

Clarke, G.M. (1998). The genetic basic of developmental stability. IV. Individual and population asymmetry parameters. Heredlty, 80: 553-561. doi: 10.1046/j.1365-2540.1998.00326.x

Cranston, P.S. \& Gullan P.J. (2017). Insetos: Fundamentos da Entomologia. $5^{\mathrm{a}}$ ed. Rio de Janeiro: Roca, $460 \mathrm{p}$

Del Sarto, M.C., Oliveira, E.E., Guedes, R.N.C. \& Campos, L.A.O. (2014). Differential insecticide susceptibility of the neotropical stingless bee Melipona quadrifasciata and the honey bee Apis mellifera. Apidologie, 45: 626-636. doi: 10.1007/s13592-014-0281-6

Domingos, H.G.T. \& Gonçalves, L.S. (2014). Thermoregulation in bees with emphasis on Apis mellifera. Acta Veterinaria Brasilica, 8: 151-154. doi: 10.21708/avb.2014.8.3.3491

Evgen'ev, M.B., Garbuz, D. \& Zatsepina, O. (2014). Heat shock proteins and whole body adaptation to extreme environments. Netherlands: Springer, $212 \mathrm{p}$

Glenny, G., Cavigli, I., Daughenbaugh, K.F. Radford, R., Kegley, S.E. \& Flenniken, M.L. (2017). Honey bee (Apis mellifera) colony health and pathogen composition in migratory beekeeping operations involved in California almond pollination. Plos One, 12: e0182814. doi: 10.1371/journal.pone.0182814

Hepburn, H.R., Radloff, S.E. \& Fuchs, S. (1999). Flight machinery dimensions of honeybees, Apis mellifera. Journal of Comparative Physiology B, 169: 107-112. doi: 10.1007/ s003600050200

Klingenberg, C.P. (2011). MorphoJ: an integrated software package for geometric morphometrics. Molecular Ecology Resources, 11: 353-357. doi: 10.1111/j.1755-0998.2010.02924.x

Klingenberg, C.P. (2015). Analyzing fluctuating asymmetry with geometric morphometrics: concepts, methods, and applications. Symmetry, 7: 843-934. doi: 10.3390/sym7020843

Klingenberg, C.P. \& Mcintyre, G.S. (1998). Geometric morphometrics of developmental instability: analyzing patterns of fluctuating asymmetry with Procrustes methods. Evolution, 52: 1363-1375. doi: 10.2307/2411306
Li, Y., Zhao, Q., Duan, X., Song, C. \& Chen, M. (2017). Transcription of four Rhopalosiphum padi (L.) heat shock protein genes and their responses to heat stress and insecticide exposure. Comparative Biochemistry and Physiology - Part A: Molecular \& Integrative Physiology, 205: 48-57. doi: 10.1016/j.cbpa.2016.12.021

Lijteroff, R., Lima, L. \& Prieri, B. (2008). Uso de líquenes como bioindicadores de contaminación atmosférica em la ciudad de San Luis, Argentina. Revista Internacional de Contaminación Ambiental, 25: 111-120.

Lima, C.B.S., Nunes, L.A., Carvalho, C.A.L., Ribeiro, M.F., Souza, B.A. \& Silva, C.S.B. (2016). Morphometric differences and fluctuating asymmetry in Melipona subnitida Ducke 1910 (Hymenoptera: Apidae) in different types of housing. Brazilian Journal of Biology, 76: 845-850. doi: 10.1590/1519-6984.01015

Lu, K., Chen, X., Liu, W. \& Zhou, Q. (2016). Identification of a heat shock protein 90 gene involved in resistance to temperature stress in two wing-morphs of Nilaparvata lugens (Stal). Comparative Biochemistry and Physiology - Part A: Molecular \& Integrative Physiology, 197: 1-8. doi: 10.1016/j. cbpa.2016.02.019

Modro, A.F.H., Marchini, L.C., Moreti, A.C.C.C. \& Maia, E. (2012). Influence of pollen on the development of Africanized bee colonies (Hymenoptera: Apidae). Sociobiology, 59: 395405. doi: 10.13102/sociobiology.v59i2.602

Møller, A.P. (1997). Developmental stability and fitness: a review. The American Naturalist, 149: 916-932.

Møller, A.P. \& Swaddle, J.P. (1997). Asymmetry, developmental stability and evolution. Oxford: Oxford University Press, 302 p

Nunes, L.A., Araújo, E.D. \& Marchini, L.C. (2015). Fluctuating asymmetry in Apis mellifera (Hymenoptera: Apidae) as bioindicator of anthropogenic environments. Revista de Biologia Tropical, 63: 673-682. doi: 10.15517/rbt.v63i3.15869

Palmer, A.R. (1994). Fluctuating asymmetry analyses: a primer. In: Markow, T.A. (Ed.), Developmental instability: its origins and evolutionary implications (pp. 335-364). Dordrecht: Kluwer Academic Publishers.

Palmer, R.A. \& Strobeck, C. (2003). Fluctuating asymmetry analyses revisited. In: Polak, M. (Ed.), Developmental instability (DI): causes and consequences (pp. 279-319). Oxford: University Press.

Parsons, P.A. (1990). Fluctuating asymmetry: An epigenetic measure of stress. Biological reviews of the Cambridge Philosophical Society, 65: 131-145. doi: 10.1111/j.1469-185X. 1990.tb01186.x

Paul, S. \& Keshan, B. (2016). Ovarian development and vitellogenin gene expression under heat stress in silkworm, Bombyx mori. Psyche, 2016: 1-8. doi: 10.1155/2016/4242317 
Pires, C.S.S., Pereira, F.M., Lopes, M.T.R., Nocelli, R.C.F., Malaspina, O., Pettis, J.S. \& Teixeira, E.W. (2016). Enfraquecimento e perda de colônias de abelhas no Brasil: há casos de CCD?. Pesquisa Agropecuária Brasileira, 51: 422-442. doi: 10.1590/S0100-204X2016000500003

Prado-Silva, A., Nunes, L.A, Santos, J.M., Affonso, P.R.A.M. \& Waldschmidt, A.M. (2018). Morphogenetic alterations in Melipona quadrifasciata anthidioides (Hymenoptera: Apidae) associated with pesticides. Archives of Environmental Contamination and Toxicology, 74: 627-632. doi: 10.1007/ s00244-018-0509-y

Rech, A.R., Agostini, K., Oliveira, P.E.G.M. \& Machado, I.C.S. (2014). Biologia da polinização. Rio de Janeiro: Editora Projeto Cultural, $524 \mathrm{p}$

Rohlf, F.J. (2017a). TpsUtil for Windows version 1.74. Department of Ecology and Evolution, State University of New York, Stony Book. Retrived from: http://life.bio.sunysb. edu/morph/index.html. Access to: 22 Ago. 2017.

Rohlf, F.J. (2017b). TpsDig for Windows version 2.30. Department of Ecology and Evolution, State University of New York, Stony Book. Retrived from: http://life.bio.sunysb. edu/morph/index.html. Access to: 22 Ago. 2017.

Roubik, D.W. (1989). Ecology and natural history of tropical bees. Cambridge: Cambridge University Press, 514 p

Simone-Finstrom, M., Li-Byarlay, H., Huang, M.H., Strand, M.K., Rueppell, O. \& Tarpy, D. R. (2016a). Migratory management and environmental conditions affect lifespan and oxidative stress in honey bees. Scientific Reports, 6: 1-10. doi: $10.1038 /$ srep32023
Simone-Finstrom, M., Walz, M. \& Tarpy, D.R. (2016b). Genetic diversity confers colony-level benefits due to individual immunity. Biology Letters, 12: 1-4. doi: 10.1098/rsbl.2015.1007

Tarpy, D.R., Lengerich, E.J. \& Pettis, J.S. (2013). Idiopathic brood disease syndrome and queen events as precursors of colony mortality in migratory beekeeping operations in the eastern United States. Preventive Veterinary Medicine, 108: 225-233. doi: 10.1016/j.prevetmed.2012.08.004

Tomkins, J.L. \& Kotiaho, J.S. (2001). Fluctuating Asymmetry. In: Encyclopedia of Life Sciences. Macmillan Publishers Ltd., Nature Publishing Group, 1: 1-5. doi: 10.1038/npg. els.0003741

Truman, J.W. \& Riddiford, L.M. (2019). The evolution of insect metamorphosis: a developmental and endocrine view. Philosophical Transactions B, 374: 2-12. doi: 10.1098/ rstb.2019.0070

vanEngelsdorp, D., Caron, D., Hayes, J., Underwood, R., Henson, M., Rennich, K., Spleen, A., Andree, M., Snyder, R., Lee, K., Roccasecca, K., Wilson, M., Wilkes, J., Lengerich, E. \& Pettis, J. (2012). A national survey of managed honey bee 2010-11 winter colony losses in the USA: results from the Bee Informed Partnership. Journal of Apicultural Research, 51: 115-124. doi: 10.3896/IBRA.1.51.1.14

Villas-Bôas, J. (2012). Manual tecnológico: Mel de abelhas sem ferrão. Brasília: Instituto Sociedade, População e Natureza, 96 p

Zhu, X., Zhou, S. \& Huang, Z.Y. (2014). Transportation and pollination service increase abundance and prevalence of Nosema ceranae in honey bees (Apis mellifera). Journal of Apicultural Research, 53: 469-471. doi: 10.3896/IBRA. 1.53.4.06

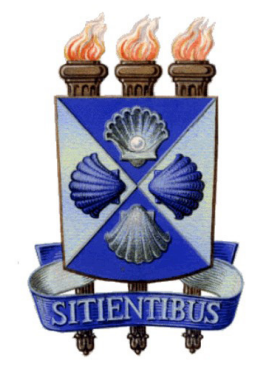

